\title{
Molecular characterization and expression of starch granule-bound starch synthase in the sink and source tissues of sweet potato
}

\author{
Shu-Jen Wang, Kai-Wun Yeh and Chia-Yin Tsai* \\ Department of Botany, National Taiwan University, Taipei, Taiwan \\ *Corresponding author,e-mail: tsaicy@ccms.ntu.edu.tw
}

Received 14 April 1999

In an effort to study regulation of starch synthesis in the source and sink tissues, a cDNA clone for starch granulebound starch synthase (GBSSI), which encodes a 67-kDa protein, was isolated from a cDNA library prepared from tuberous roots of sweet potato (Ipomoea batatas Lam. cv. Tainong 62). This GBSSI protein contains a signal peptide of 77 amino acids, and the mature protein has a molecular mass of about $59 \mathrm{kDa}$. The mature protein shares $75-85 \%$ sequence identity with GBSSIs of dicotyledonous plants and about $\mathbf{7 0} \%$ identity with those of monocotyledons. The sequence of the signal peptide, on the other hand, differs substantially from those of the dicotyledons and monocotyledons studied, although their hydropathic profiles are all similar.
This GBSSI gene was well expressed in tuberous roots, leaves, and stems, but not in roots. However, mechanisms involved in regulating the expression of this gene were different between tuberous roots and leaves. In tuberous roots, the synthesis of GBSSI transcript increased coordinately with tuberous root expansion; nevertheless, accumulation rates of GBSSI protein in starch granules remained constant regardless of tuberous root sizes, suggesting an involvement of post-transcriptional regulation for the synthesis of this protein. The levels of GBSSI transcript were investigated in photosynthetic tissues during diurnal cycles, and the results suggest that the transcription of the GBSSI gene in leaves is controlled by the endogenous circadian rhythm.

\section{Introduction}

Starch synthase (EC 2.4.1.21) is an important enzyme responsible for the biosynthesis of starch in plant tissues (DeFekete et al. 1960, Nelson and Tsai 1964). This enzyme includes two major forms, namely, starch granule-bound starch synthase (GBSS) and soluble starch synthase (SSS). GBSS is also known as the WAXY protein, which is tightly associated with starch granules (Tsai 1974), while SSS can be found in the soluble fraction of amyloplasts or the stroma of chloroplasts (Preiss 1988). Biochemical properties of GBSS and SSS are different. GBSS transfers glucose units from adenosine $5^{\prime}$-diphosphate (ADP)-glucose or uridine 5'-diphosphate (UDP)-glucose to non-reducing ends of $\alpha-1,4$ glucose polymers, although the rate of transfer from ADP-glucose is higher than from UDP-glucose; in contrast, SSS uses ADP-glucose as the sole substrate (Tsai 1974). A previous study showed that GBSS preferred amylose over amylopectin as a primer while SSS would only add the glucose unit into amylopectin (Tsai 1973).
Several waxy mutants have been identified that contain amylose-free starch, and these mutants are deficient in the GBSS activity (Nelson and Tsai 1964, Hovenkamp-Hermelink et al. 1987); furthermore, the activity of GBSS is proportional to the number of $W x$ allele (Tsai 1974), suggesting the importance of GBSS in amylose synthesis. Studies using an antisense technique also confirm the importance of GBSS in amylose formation (Visser et al. 1991a, Salehuzzaman et al. 1993). GBSS can be classified into different types based on the molecular mass and localization: (1) GBSSI with a molecular mass of $58-60 \mathrm{kDa}$ is tightly bound to starch granules and offers the largest proportion of total GBSS activity (Shure et al. 1983, Vos-Scheperkeuter et al. 1986, Dry et al. 1992). In some plant species, multiple isoforms of GBSSI have been identified and their expressions are tissue-specific (Denyer et al. 1997, Nakamura et al. 1998, Tomlinson et al. 1998). Studies on a waxy mutant of wheat and low-amylose (lam) mutant of pea indicate that

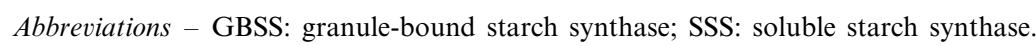


GBSSI plays little function in non-storage organs; instead, another GBSSI-like protein replaces the GBSSI to synthesize amylose in those tissues (Denyer et al. 1997, Nakamura et al. 1998, Tomlinson et al. 1998). However, a single GBSSI isoform is responsible for amylose synthesis in tubers, leaves, roots, and pollens of potato (Jacobsen et al. 1989). Although GBSSI may exist in different isoforms, these observations clearly indicate the involvement of GBSSI in amylose formation. The waxy mutants of potato, barley, and maize characterized so far are all associated with a loss of GBSSI activity (Hovenkamp-Hermelink et al. 1987, Hylton et al. 1996). (2) GBSSII (also referred to as SSII) with a molecular mass of $77-79 \mathrm{kDa}$ is present in starch granules as well as in the soluble fraction of plastids (Dry et al. 1992, Denyer et al. 1993, 1995, Edwards et al. 1995, 1996, Hylton et al. 1996, Craig et al. 1998). In contrast to GBSSI, the role of GBSSII remains ambiguous. A reduction of this activity in potato tubers did not affect the ratio of amylose to amylopectin (Edwards et al. 1995); however, a study on rugosus5 (rug5) mutant of pea suggests that GBSSII might play an important role for determining amylopectin structure and starch granule morphology (Craig et al. 1998).

In addition, another type of starch synthase with a molecular mass of $140 \mathrm{kDa}$, SSIII, has been purified from potato tubers (Marshall et al. 1996). SSIII contributes about $80 \%$ of the activity found in the soluble fraction, and it may also bind to starch granules. The antisenseSSIII transgenic potato did not show a change in the starch content nor in the amylose-to-amylopectin ratio in tubers; however, the morphology of starch granules and the amylopectin branching patterns were significantly different from those of the wild type (Abel et al. 1996, Marshall et al. 1996, Edwards et al. 1999).

Although the role of GBSSI in starch synthesis has been established, expression and regulation of this gene in the sink and source tissues remain unclear. Assimilate availability from the source and the ability of the sink to accumulate starch have been recognized as two major factors for yield determination of agronomic crops. Leaf is an important source tissue in which starch formed during the day is mobilized at night to provide the carbon source for starch synthesis in the sink. Storage sink is a non-photosynthetic tissue where starch deposition is a major biochemical process during development and maturation. Thus, a positive interaction between the two tissues should favor starch accumulation in the sink. A reduction of starch synthesis in sink tissues not only reduces yield but also produces important pleiotropic effects during development (Tsai 1983, Martin and Smith 1995). For example, the inhibition of starch synthesis in the sink may result in a high osmotic potential and reduce the content of storage protein (Tsai et al. 1978, Lee and Tsai 1985, MüllerRöber et al. 1992). Since source-sink interactions play such a vital role in determining yield (Tsai and Tsai 1990) and GBSS is important for starch synthesis, efforts were made to investigate regulatory mechanisms involved in controlling the expression of the GBSS gene in the sink and source tissues of sweet potato.

\section{Materials and methods}

\section{Plant material}

Sweet potato (Ipomoea batatas Lam. cv. Tainong 62) was grown at Tauyan District Agricultural Improvement station in northern Taiwan. Sweet potato was planted in July 1996, and tuberous roots of different sizes were harvested in September. After harvest, these tuberous roots were brought into laboratory for processing. For photoperiod experiments, plants were grown and maintained at $28^{\circ} \mathrm{C}$ in a growth chamber under $16 \mathrm{~h}$ light $/ 8 \mathrm{~h}$ dark. To initiate the study, some plants were moved to separate chambers after the $8 \mathrm{~h}$ dark period and then treated continuously with $24 \mathrm{~h}$ light or $24 \mathrm{~h}$ dark, respectively. Leaf samples were then harvested at the time intervals indicated.

\section{Isolation of DNA and RNA from sweet potato}

Genomic DNA was isolated according to the procedure of Dellaporta et al. (1983) with some modifications. A sample of tuberous roots $(20 \mathrm{~g})$ was ground in liquid nitrogen, transferred into a flask containing $50 \mathrm{ml}$ of extraction buffer (100 mM Tris-HCl, pH 8.0, $50 \mathrm{~m} M$ ethylenediaminetetraacetate [EDTA], $500 \mathrm{mM} \mathrm{NaCl}, 100 \mu \mathrm{g} \mathrm{ml}^{-1}$ proteinase $\mathrm{K}$ ), and then incubated at room temperature with gentle shaking for $20 \mathrm{~min}$ before centrifugation at $12000 \mathrm{~g}$ for $10 \mathrm{~min}$. The supernatant received $3 \mathrm{ml}$ of $20 \%(\mathrm{w} / \mathrm{v})$ sodium dodecyl sulphate (SDS), was incubated at $55^{\circ} \mathrm{C}$ for $1 \mathrm{~h}$, and then centrifuged at $12000 \mathrm{~g}$ for 20 min. After centrifugation, the supernatant was mixed with 0.1 volume of $3 M$ potassium acetate $(\mathrm{pH} 5.2)$ and 0.6 volume of isopropanol; the mixture was kept at $-20^{\circ} \mathrm{C}$ for $30 \mathrm{~min}$ before centrifugation at $12000 \mathrm{~g}$ for $10 \mathrm{~min}$ at $4^{\circ} \mathrm{C}$. The pellet containing DNA was dissolved in $2 \mathrm{ml}$ of TE buffer (10 mM Tris-HCl, pH 8.0, $1 \mathrm{~m} M$ EDTA) before re-extracting in succession with equal volume of phenol:chloroform:isoamylalcohol $(25: 24: 1, \mathrm{v} / \mathrm{v} / \mathrm{v})$ and chloroform:isoamylalcohol $(24: 1, \mathrm{v} / \mathrm{v})$. After centrifugation, DNA in the supernatant was precipitated with $5 \mathrm{ml}$ of $100 \%$ ethanol and $0.2 \mathrm{ml}$ of $3 \mathrm{M}$ sodium acetate, $\mathrm{pH} 5.2$. Finally, the DNA pellet was dissolved in $0.5 \mathrm{ml}$ of TE buffer or $\mathrm{H}_{2} \mathrm{O}$.

RNA was isolated from tuberous roots, leaves, stems, or roots according to the procedure described by Yeh et al. (1991). Poly(A) ${ }^{+}$RNAs were isolated by oligo(dT) cellulose column chromatography (Shennan 1996). For determining expressions of the GBSSI gene, total RNAs $(10 \mu \mathrm{g}$ for each sample) were separated on $1 \%$ formaldehydeagarose gels (Sambrook et al. 1989), and probed with $G B$ SSI cDNA of sweet potato (spss67 clone). rRNA was used as an internal standard. All experiments were repeated at least twice.

\section{Preparation of a DNA probe}

GBSSI sequences of potato (van der Leij et al. 1991) and cassava (Salehuzzaman et al. 1993) were selected from the GenBank and then aligned by Wisconsin Genetics Computer Group (GCG) software to identify conserved re- 
gions. Two primers were designed for amplifying a part of sweet potato GBSSI gene that contained the first consensus region (BOX 1) of starch synthase genes using reverse transcription-polymerase chain reaction (RT-PCR). The sequence of sense and antisense primers were [5'-TGGAGCAAAACTGGAGGTCT-3'] and [5'-GTGCCAATCATTGGCAATG-3'], respectively (see also Fig. 1). Tuberous root poly $(\mathrm{A})^{+}$RNAs $(0.5 \mu \mathrm{g})$ of sweet potato were used as templates, and the first strand cDNAs was synthesized by RAV2 reverse transcriptase (Amersham, Buckinghamshire, UK). The PCR reaction was completed by Taq DNA polymerase (Promega, Madison, WI, USA). The RT-PCR was conducted according to the procedure described by Goodbourn (1996). Final amplification generated a $0.4-\mathrm{kb}$ DNA fragment.

\section{Construction and screening of a cDNA library}

cDNAs were synthesized from poly $(\mathrm{A})^{+}$RNAs prepared from tuberous roots of sweet potato by using a GIBCO BRL cDNA synthesis kit. The cDNAs obtained were methylated by Eco RI methylase and ligated to an Eco RI linker. After digestion with EcoRI, the cDNAs were ligated into the EcoRI site of $\lambda \mathrm{gt} 10$ (Promega). Approximately, $1 \times 10^{5}$ p.f.u. were screened according to the procedure described by Sambrook et al. (1989) using the 0.4-kb RT-PCR fragment as a probe.

\section{Subcloning and sequencing}

The RT-PCR product (0.4-kb DNA fragment) was ligated into the SmaI site of pGEM3Z (Promega). The selected cDNA clones were subcloned into the EcoRI site of pGEM7Z (Promega) before unidirectional deletion with exonuclease III (ExoIII) and S1 nuclease to obtain different sizes of nested deletion clones (Henikoff 1984). DNA sequences were determined according to the method of Sanger et al. (1977) and analysis was performed using the Wisconsin GCG Software Package version 9.0 (Devereux et al. 1984).

\section{Southern and northern blot analyses}

For the Southern blot analysis, sweet potato genomic DNA $(10 \mu \mathrm{g})$ was digested with Eco RI, HindIII, or XbaI, and the digested DNA was separated on a $0.65 \%$ agarose gel and blotted onto a nitrocellulose membrane (Amersham). For the northern blot analysis, total RNAs $(10 \mu \mathrm{g})$ were separated on $1.0 \%$ formaldehyde-agarose gels (Sambrook et al. 1989). The DNA probe was radioactively labeled with $\alpha-{ }^{32} \mathrm{P}-\mathrm{dCTP}$ using a random primer labeling kit (Amersham). After hybridization, the membranes were washed twice with $2 \times$ SSC (1 1 of $20 \times$ SSC stock solution contained $175.3 \mathrm{~g}$ of $\mathrm{NaCl}$ and $88.2 \mathrm{~g}$ of sodium citrate, $\mathrm{pH} 7.0)$ containing $0.1 \%(\mathrm{w} / \mathrm{v})$ SDS at room tem- perature for $30 \mathrm{~min}$ and twice with $0.1 \times$ SSC containing $0.1 \%(\mathrm{w} / \mathrm{v}) \mathrm{SDS}$ at $55^{\circ} \mathrm{C}$ for $30 \mathrm{~min}$ (Sambrook et al. 1989).

\section{Expression of GBSSI in Escherichia coli}

The coding region of GBSSI cDNA was amplified by PCR using the following primer pairs: sense primer [5'TCGGATCCATGGCGACTATAACTGC-3'], and antisense primer [5'-TCGAATTCGGTGGAGTAGCGACGTT-3']. The amplified fragment was constructed into Bam HI-Eco RI cloning sites of pET-21a vector (Novagen, Madison, WI, USA). This constructed plasmid was transferred into $E$. coli strain BL21 (DE3) and incubated in Luria broth (LB) medium containing ampicillin (50 $\mu \mathrm{g}$ $\mathrm{ml}^{-1}$ ) as a selective antibiotic. Expression of the target gene was induced by $1 \mathrm{~m} M$ isopropyl $\beta$-D-thiogalactopyranoside for $3 \mathrm{~h}$.

\section{Isolation of starch granules and GBSSI enzyme}

Tissue samples $(2 \mathrm{~g})$ were powdered in liquid nitrogen with a mortar and pestle, and subsequently ground with $10 \mathrm{ml}$ of buffer (50 m $M$ Tris- $\mathrm{HCl}$, pH 7.5, $10 \mathrm{~m} M$ EDTA, $2 \mathrm{~m} M$ dithiothreitol [DTT]) before filtering through two layers of Miracloth (Calbiochem, La Jolla, CA, USA) and centrifuging at $12000 \mathrm{~g}$ for $10 \mathrm{~min}$ at $4^{\circ} \mathrm{C}$. The pellet including starch granules was washed 3 times with ice-cold extraction buffer followed by 4 times with cold acetone (Tsai 1974). For SDS-polyacrylamide gel analyses, the starch granule-bound proteins were extracted from $15 \mathrm{mg}$ of starch granules by SDS-sample buffer (Salehuzzaman et al. 1993) before electrophoresis on 7.5\% SDS-polyacrylamide gels (Laemmli 1970).

\section{Western blot analysis and N-terminal sequencing of the GBSSI protein}

Proteins were separated on a 7.5\% SDS-polyacrylamide gel and transferred to nitrocellulose membrane (Amersham) for western blot analysis using an antibody raised against the potato GBSSI (kindly provided by Dr R. Visser). For $\mathrm{N}$-terminal sequencing of the GBSSI protein, GBSSI was purified from starch granules by separation on 7.5\% SDSpolyacrylamide gels and transferred to a polyvinylidene difluoride membrane (Millipore, Bedford, MA, USA). GBSSI was excised from the membrane and an N-terminal amino acid sequence obtained using a Perkin Elmer (Norwalk, CT, USA) Applied Biosystem 477A protein sequenator.

\section{In vivo labeling of tuberous roots}

Small discs (each disc weighed about $2 \mathrm{~g}$ with a dimension of $1 \times 0.5 \times 0.3 \mathrm{~cm})$ were cut from sweet potato tuberous roots, incubated in $5 \mathrm{ml}$ shaking buffer $(0.1 \%[\mathrm{w} / \mathrm{v}]$ sucrose, $5 \mathrm{~m} M$ phosphate buffer, $\mathrm{pH} 6.0,50 \mathrm{mg} \mathrm{ml}^{-1}$ chlorampheni$\mathrm{col}$ ), and gently shaken at $25^{\circ} \mathrm{C}$ for $30 \mathrm{~min}$. Subsequently, the sample discs were shaken for $4 \mathrm{~h}$ after $1.85 \mathrm{MBq}$ of ${ }^{35}$ S-methionine (37 $\mathrm{PBq} \mathrm{mol}{ }^{-1}$; Amersham) was added. 


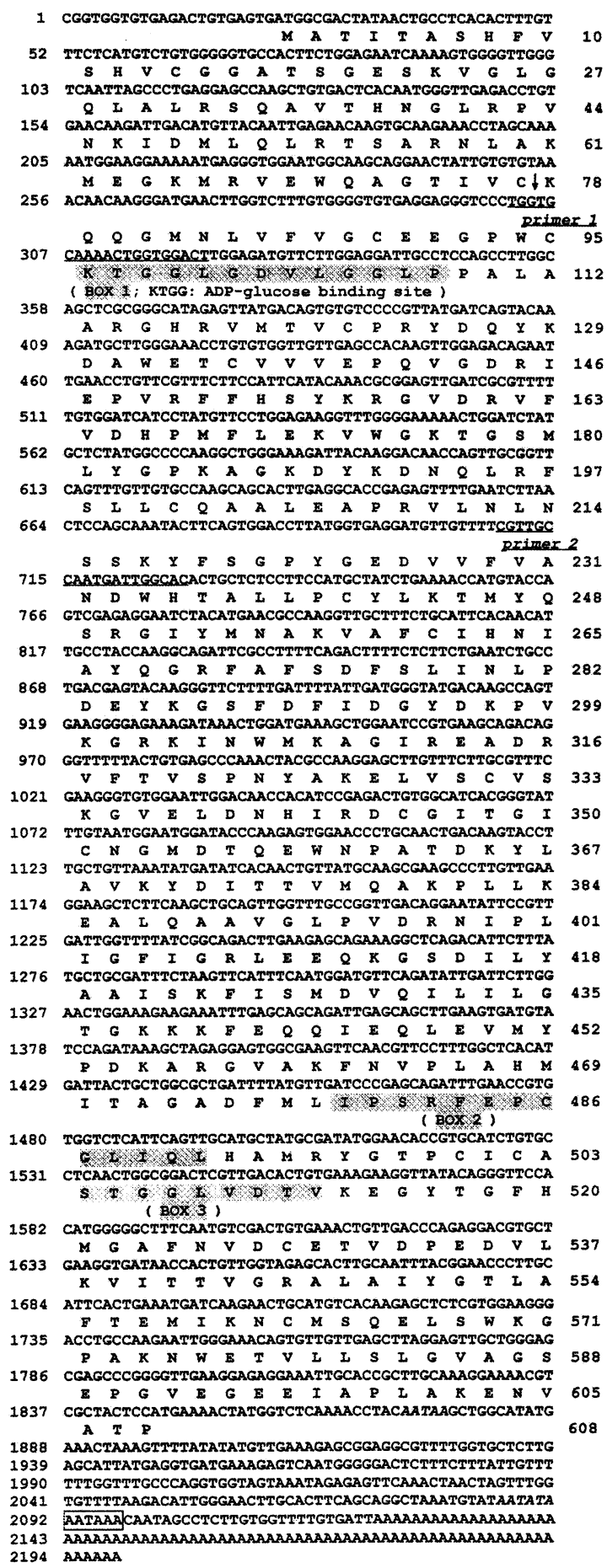

Fig. 1. Nucleotide and deduced amino acid sequence of the cDNA (spss67) encoding sweet potato GBSSI. The conserved regions of starch synthases are shaded and labeled BOX 1, 2, and 3; indicates the signal peptide cutting site. The typical polyadenylation signal is boxed. Primer pairs for generating 0.4-kb DNA probes (a part of GBSSI gene) are underlined and shown as primer 1 and 2. The nucleotide sequence has been assigned accession number U44126 in the GenBank database.

After incubation, the discs were washed 5 times with washing buffer $(0.1 \%$ sucrose, $5 \mathrm{~m} M$ phosphate buffer, $\mathrm{pH}$ 6.0, $1 \mathrm{mM}$ methionine) before extraction of starch granules and granule- bound proteins (Salehuzzaman et al. 1993). The extracted proteins were analyzed by one-dimensional SDS-polyacrylamide gel electrophoresis according to Laemmli (1970). After electrophoresis, the gel was fixed in a solution containing $10 \%$ $(\mathrm{w} / \mathrm{v})$ trichloroacetic acid, $10 \%(\mathrm{v} / \mathrm{v})$ glacial acetic acid and $30 \%(\mathrm{v} / \mathrm{v})$ methanol. Radioactive protein bands were detected by fluorography (Larskey and Mills 1975). The dried gel was exposed to Kodak BioMax film (Eastman-Kodak, Rochester, NY, USA) at $-70^{\circ} \mathrm{C}$ for 5 days.

\section{Results}

Isolation and characterization of starch synthase cDNA clones

A $0.4-k b$ fragment was obtained by RT-PCR using two primers designed for a consensus region of dicotyledonous $G B S S$ genes, a region which includes the ADP-glucose binding site. This $0.4-\mathrm{kb}$ sweet potato fragment showed a high sequence identity to the corresponding parts of the potato (van der Leij et al. 1991) and cassava (Salehuzzaman et al. 1993) genes (77.6 and 77.7\%, respectively). This result indicates that the fragment was a partial sequence encompassing the first consensus region of the starch synthase gene in sweet potato. Therefore, it was used as a probe for isolating starch synthase genes in this study. When the tuberous root cDNA library was screened with this probe, six positive clones were isolated from $1 \times 10^{5}$ p.f.u. Only one of them contained 2199 bp (spss67) with a full length open reading frame (ORF) encoding 608 amino acids (Fig. 1), while others all contained a partial sequence of this clone. This clone has been assigned accession number U44126 in the GenBank database.

Nucleotide sequencing showed that the spss67 starch synthase cDNA clone contained $22 \mathrm{bp}$ in the $5^{\prime}$ nontranslated region, $350 \mathrm{bp}$ in the $3^{\prime}$ noncoding region, and had an ORF of $1827 \mathrm{bp}$ which encodes a $67-\mathrm{kDa}$ protein with a predicted pI value of 7.46. A typical polyadenylation signal AATAAA is located at 32 nucleotides upstream of the poly(A) tail. Comparison of the deduced amino acid sequence of spss 67 with other starch synthases shows a high sequence identity with GBSSI of various plant species $(65-80 \%)$, but a low identity with GBSSII (SSII) and SSIII of potato and with SSS of rice (Table 1). The spss 67 cDNA exhibits three consensus regions, BOX 1, 2 and 3, characteristics of starch synthases (Fig. 1). BOX 1, i.e., Lys-Thr-Gly-Gly (KTGG), is known to be in the ADP-glucose binding site. Southern analysis indicated that only one copy of GBSSI is present in the sweet potato genome (data not shown).

\section{Characteristics of the GBSSI protein}

In order to characterize the product of the spss67 clone, spss67 cDNA was constructed into a pET-21a expression vector and transferred into E. coli BL21 (DE3) strain. The transformants over-expressed a $67-\mathrm{kDa}$ protein, which agreed with the molecular mass predicted from the spss 67 cDNA, and this protein could be recognized by an antiserum raised against the GBSSI protein isolated from starch granules of potato (Fig. 2B, lane 4). Although the spss67 
Table 1. Sequence comparisons of sweet potato GBSSI cDNA (spss67) and protein with those of other plant species. Data obtained from Wisconsin GCG Software Package version 9.0.

\begin{tabular}{|c|c|c|c|c|c|}
\hline $\begin{array}{l}\text { Species (EMBL/GenBank accession num- } \\
\text { bers of the nucleotide sequences) }\end{array}$ & $\begin{array}{l}\text { Nucleotide se- } \\
\text { quence identity } \\
(\%)\end{array}$ & $\begin{array}{l}\text { Full length } \\
\text { protein identity } \\
(\%)\end{array}$ & $\begin{array}{l}\text { Signal peptide } \\
\text { identity }(\%)\end{array}$ & $\begin{array}{l}\text { Mature protein } \\
\text { identity }(\%)\end{array}$ & Reference \\
\hline \multicolumn{6}{|l|}{ GBSSI } \\
\hline \multicolumn{6}{|l|}{ Dicotyledons } \\
\hline Potato (X58453) & 77.0 & 79.3 & 46.7 & 84.0 & $\begin{array}{l}\text { van der Leij et } \\
\text { al. }(1991)\end{array}$ \\
\hline Cassava (X74160) & 73.8 & 73.5 & 33.8 & 79.1 & $\begin{array}{l}\text { Salehuzzaman et } \\
\text { al. (1993) }\end{array}$ \\
\hline Pea (X88789) & 72.9 & 70.4 & 39.4 & 74.5 & Dry et al. (1992) \\
\hline \multicolumn{6}{|l|}{ Monocotyledons } \\
\hline Barley (X07932) & 66.4 & 65.9 & 30.3 & 70.7 & $\begin{array}{l}\text { Rohde et al. } \\
\text { (1988) }\end{array}$ \\
\hline Wheat (X57233) & 66.1 & 64.8 & 30.3 & 69.4 & $\begin{array}{l}\text { Clark et al. } \\
\text { (1991) }\end{array}$ \\
\hline Rice (X62134) & 67.6 & 65.0 & 27.5 & 70.2 & Okagaki (1992) \\
\hline \multicolumn{6}{|l|}{ GBSSII (SSII) } \\
\hline Potato (X87988) & 56.0 & 38.7 & - & - & $\begin{array}{l}\text { Edwards et al. } \\
(1995)\end{array}$ \\
\hline \multicolumn{6}{|l|}{ SSIII } \\
\hline Potato (X95759) & 66.7 & 43.2 & - & - & $\begin{array}{l}\text { Marshall et al. } \\
\text { (1996) }\end{array}$ \\
\hline \multicolumn{6}{|r|}{ (1) } \\
\hline Rice (D16202) & 58.7 & 39.1 & - & - & $\begin{array}{l}\text { Baba et al. } \\
(1993)\end{array}$ \\
\hline
\end{tabular}

cDNA encodes a $67-\mathrm{kDa}$ protein, the mature GBSSI of sweet potato has a molecular mass of only $59 \mathrm{kDa}$ (Fig. 2). Comparison of the N-terminal amino acid sequence of GBSSI deduced from the spss 67 cDNA sequence with that of the mature GBSSI isolated from tuberous roots demonstrates that the GBSSI preprotein should contain a transit peptide of 77 amino acids with a molecular mass of about $8.2 \mathrm{kDa}$. The transit peptide sequence of sweet potato GBSSI shows an identity of $27-47 \%$ with those of other plant species (Table 1); however, like other GBSSI transit peptides, it has hydrophobic regions in the initiation and end of the peptide (data not shown).

\section{Expression of GBSSI in the sink and source tissues}

Like tuberous roots and leaves, stems also accumulated starch (Fig. 3C). The level of starch accumulation per unit fresh weight was higher in tuberous roots than in leaves and stems (Fig. 3C). As expected, GBSSI transcripts (Fig. 3A) and proteins (Fig. 3B) were accumulated in tuberous roots, leaves, and stems. In roots, expression of the GBSSI gene was not detectable (Fig. 3A). In tuberous roots, the GBSSI transcript increased along with the size of tubers (Fig. 4A); however, immunoblot analysis showed that protein levels of GBSSI remained relatively constant when isolated from 15 $\mathrm{mg}$ of starch granules prepared from tuberous roots of different sizes (Fig. 4B). As shown in Fig. 4C, there is no correlation between the accumulation of GBSSI transcript and protein levels during the development of tuberous roots when expressed on a unit fresh weight basis. In order to determine factors causing the discrepancy between transcript and protein accumulation patterns, the protein accumulation rate during development was analyzed by incorporation of ${ }^{35} \mathrm{~S}$-methionine into GBSSI protein in vivo. The result of in vivo labeling indicated that accumulation rates of GBSSI were similar in tuberous roots of different sizes (Fig. 5). Therefore, these observations suggest that some post-tran-

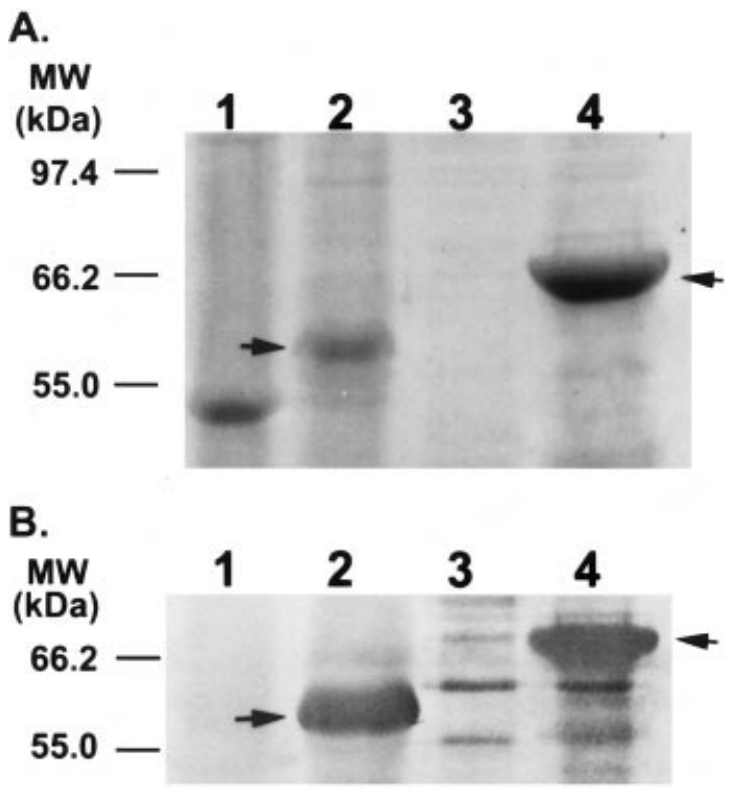

Fig. 2. Identification of mature GBSSI protein in sweet potato tuberous roots and recombinant GBSSI protein from E. coli. Lane 1 , soluble protein fraction from tuberous roots; lane 2, starch granule-bound proteins of tuberous roots; lane 3 , inclusion body fraction from the control $E$. coli strain; lane 4, inclusion body fraction from the GBSSI cDNA (spss67) transformed E. coli strain. Proteins were stained with Coomassie Brilliant Blue on a $7.5 \%$ SDS-PAGE (A) and immunoblotted with antiserum against the GBSSI of potato (B). Arrows indicate the GBSSI. 
A.

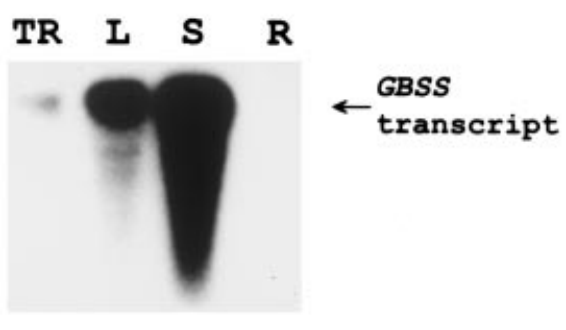

B.

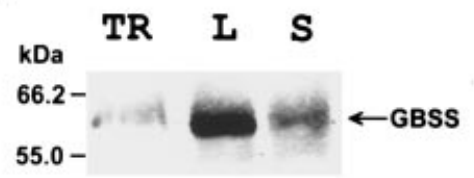

C.

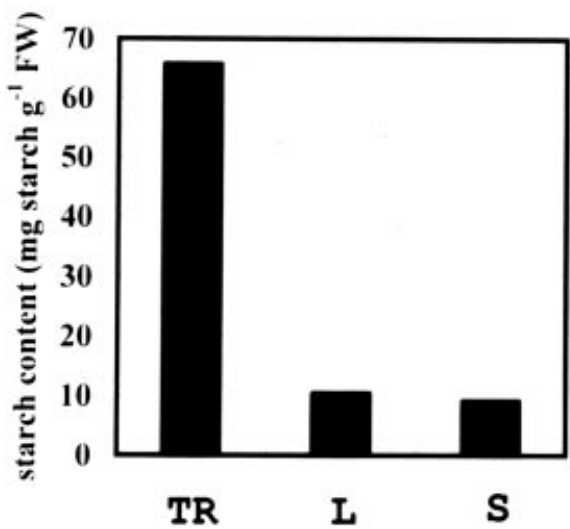

Fig. 3. Expression of GBSSI and starch content in tissues of sweet potato. (A) The levels of GBSSI transcript were determined by northern blot analysis. Total RNAs $(10 \mu \mathrm{g})$ were separated on a $1 \%$ formaldehyde-agarose gel, transferred onto nitrocellulose membranes and hybridized with ${ }^{32} \mathrm{P}$-labeled GBSSI cDNA (spss67 clone) probe. (B) GBSSI protein of different tissues was detected by antiserum against the GBSSI of potato. (C) Starch content. TR, tuberous root; L, leaf; S, stem; R, root.

scriptional mechanisms were involved in regulating the expression of GBSSI in tuberous roots.

To study the effect of photoperiod on GBSSI gene expression in leaves, the expression pattern of the GBSSI transcript was determined from plants grown under $16 \mathrm{~h} \mathrm{light} / 8$ $\mathrm{h}$ dark as a control. During the 24-h period, the GBSSI mRNA accumulated abundantly after 2-h treatment of light and then decreased slightly at $8 \mathrm{~h}$, and almost completely disappeared at $12 \mathrm{~h}$ (Fig. 6A). However, the transcript reappeared at the end of the 24 -h period, i.e., after $8 \mathrm{~h}$ dark. In order to determine whether the diurnal expression pattern was controlled by environmental stimuli or circadian rhythm, the $16 \mathrm{~h}$ light $/ 8 \mathrm{~h}$ dark photoperiod adapted plants were shifted to $24 \mathrm{~h}$ continuous light or $24 \mathrm{~h}$ continuous dark before RNA isolation. A similar GBSSI expression pattern was observed for these treatments (Fig. 6B,C). Levels of rRNA internal standard were similar in all treatments (data not shown).

\section{Discussion}

A cDNA clone (spss67) containing a full length ORF, which encodes a GBSSI protein, was isolated from a tuberous root cDNA library of sweet potato (Fig. 1). This cDNA shared a high sequence identity with that of those coding for starch synthases in other plants (Table 1), and it contained a typical polyadenylation signal located 32 nucleotides upstream of the poly(A) tail. Sequence analysis indicated that GBSSI of sweet potato contains a transit peptide of 77 amino acids at the $\mathrm{N}$-terminus. The peptide was similar in size to the GBSSI transit peptide of potato (van der Leij et al. 1991), but was larger than that of maize (Klösgen et al. 1986). However, the amino acid sequences of these transit peptides were all rather different (Table 1) although their hydropathic profiles were very similar (data not shown). These observations are consistent with the notion that the secondary structure and hydropathic distributions of transit peptides are more important than the amino acid sequence per se for function (Keegstra et al. 1989).

Unlike the transit peptide, the sequence of the GBSSI mature protein appears to be well conserved. The mature GBSSI of sweet potato shows $70-85 \%$ amino acid identity with GBSSIs of other plant species. The ADP-glucose binding site (KTGG) of GBSSI, located within BOX 1, agrees

A.
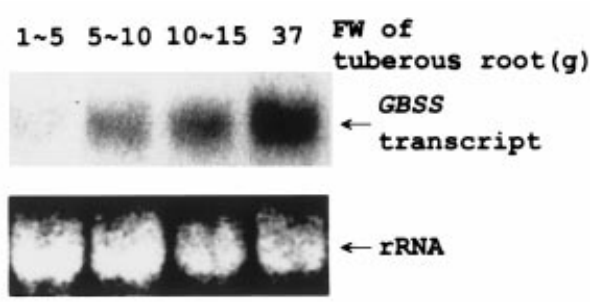

B.

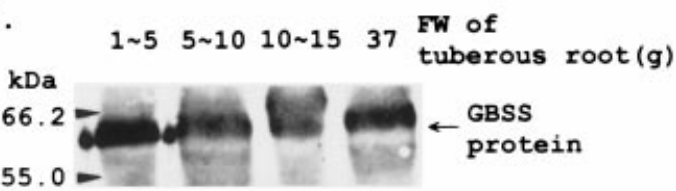

C.

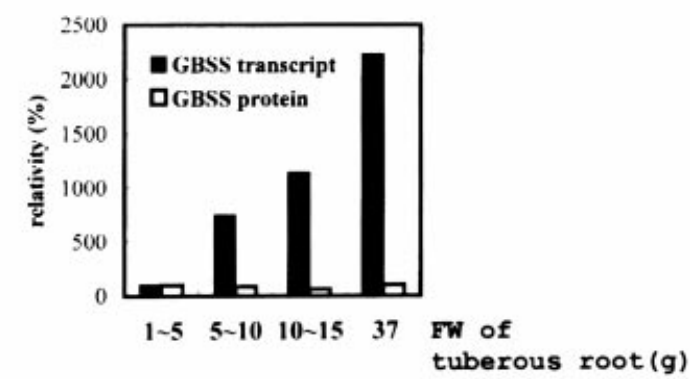

Fig. 4. Expression of the GBSSI gene in tuberous roots. (A) Total RNAs $(10 \mu \mathrm{g})$ of tuberous roots of different sizes were separated on a $1 \%$ formaldehyde-agarose gel and probed with ${ }^{32} \mathrm{P}$-labeled $G B S S I$ cDNA (spss67 clone); rRNA was used as an internal control. (B) GBSSI protein was extracted from $15 \mathrm{mg}$ of starch granules and detected by immunoblotting. (C) Relative levels of GBSSI transcript and protein in tuberous roots of different sizes. The content of GBSSI transcript and protein in (C) are expressed on the basis of per unit fresh weight, and relative levels are based on the measurement determined for the smallest tuberous root $(100 \%)$. 


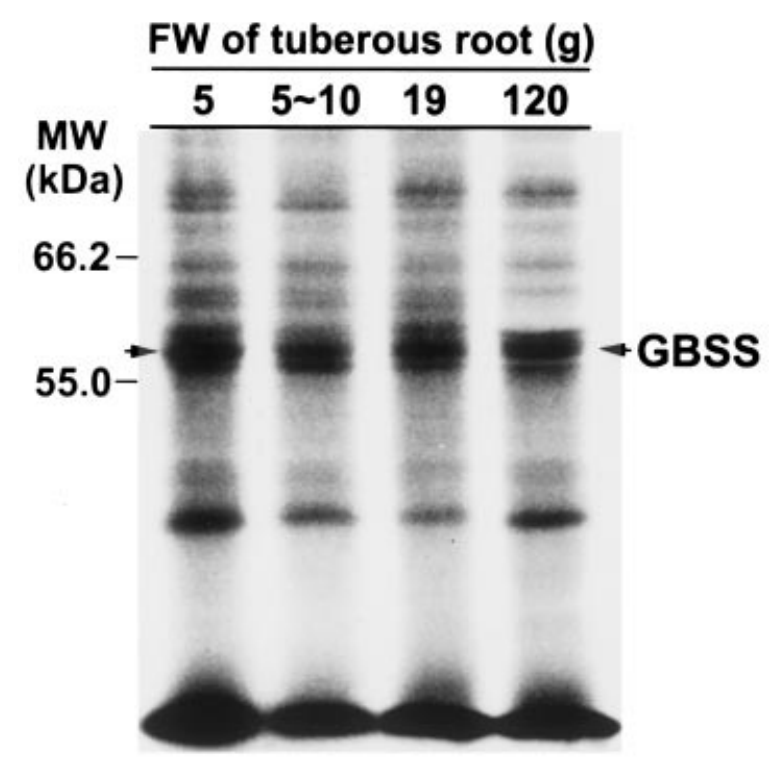

Fig. 5. Autoradiograph demonstrating the in vivo labeling of GBSSI protein in tuberous roots of different sizes. Twenty microliters of ${ }^{35} \mathrm{~S}$-labeled starch granule-bound proteins (extracted from $2 \mathrm{~g}$ of treated tuberous root discs) were separated on a $10 \%$ SDS-gel. $\rightarrow$ Indicates the GBSSI; the signals of labeled GBSSI were confirmed by comparing with the location of mature GBSSI protein identified by immunoblotting and staining with Coomassie Brilliant Blue.

with starch synthases of other plants, and is similar to the $\mathrm{KXGG}$ found in E. coli and mammalian glycogen synthases (Furukawa et al. 1990). Although GBSS utilizes ADP-

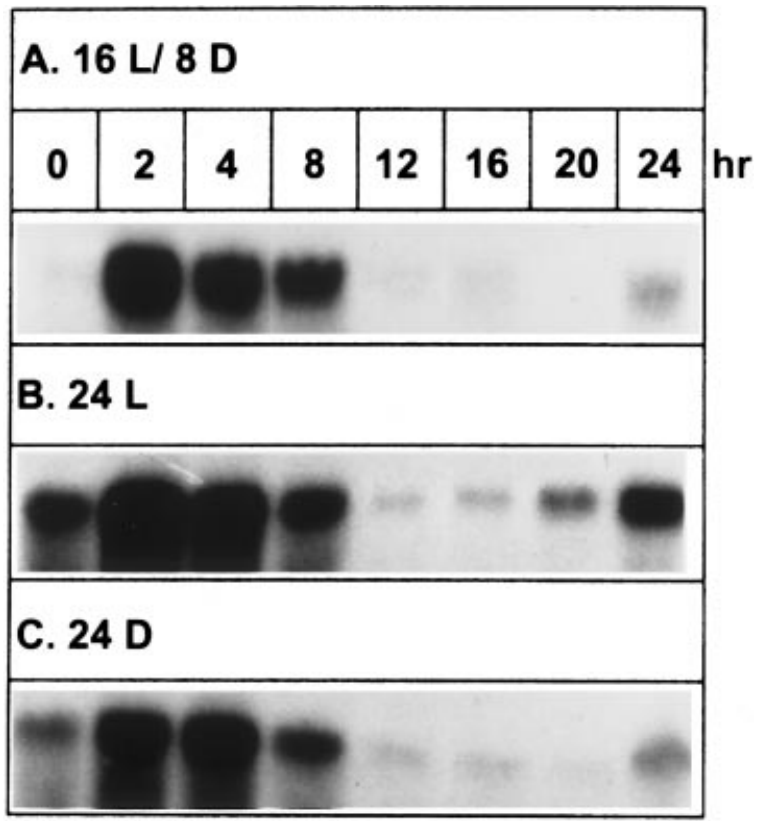

Fig. 6. Expression of the GBSSI gene in leaves under different photoperiods. Plants were cultured under $16 \mathrm{~h}$ light $/ 8 \mathrm{~h}$ dark as the control (A). Plants were moved to continuous light (B) or dark (C) after being kept under $16 \mathrm{~h}$ light $/ 8 \mathrm{~h}$ dark condition for 7 days. RNAs were extracted from leaves harvested at the time intervals indicated. Total RNAs $(10 \mu \mathrm{g})$ were separated on a $1 \%$ formaldehyde-agarose gel and probed with ${ }^{32} \mathrm{P}$-labeled GBSSI cDNA (spss 67 clone). glucose and UDP-glucose as substrates, the substrate binding sequence is identical to that of SSS, which uses ADPglucose as the sole substrate (Tsai 1973). This result suggests that sequences other than the KTGG might also be involved in determining substrate specificity.

Non-photosynthetic storage organs (sink) and photosynthetic leaves (source) are major sites for starch synthesis, but the property and structure of starch produced are different between these two sites (Tomlinson et al. 1997). Expression of some genes involved in the starch synthetic pathway appear to be regulated by different mechanisms in sink and source tissues (Nakata and Okita 1995). Identification and characterization of the GBSSI gene expression enabled us to study regulatory mechanisms of this gene in the two tissues. In addition to tuberous roots and leaves, the GBSSI gene was highly expressed in stems (Fig. 3A). A similar observation was made in potato. Visser et al. (1991b) analyzed the expression of a chimeric GBSSI promoter-GUS gene in transgenic potato, and their results indicated that GUS activity in stems was higher than in leaves. Thus, the observations obtained with sweet potato and potato appear to be different from those obtained with cassava, rice, and maize where the expression of GBSSI is tissue-specific with transcripts accumulated primarily in the storage organs, such as tubers and endosperms (Klösgen et al. 1986, Salehuzzaman et al. 1993). It is not clear why stems contained a high level of GBSSI mRNA. We suggest that leaves and stems might share a common mechanism to control GBSSI expression. Changes in the accumulation of GBSSI transcript in stems were similar to those of leaves during diurnal cycles (unpublished data), and starch contents were similar in leaves and stems when they were harvested at the same time (Fig. 3C). It should also be noted that relative amounts of GBSSI mRNA in tuberous roots, stems, and leaves could not be determined in an absolute term because the amounts changed independently in each tissue and varied substantially depending on stages of sampling.

Tuberous root is a major sink tissue for the storage of starch. As expected, the accumulation of GBSSI transcript increased concomitantly with the size of tuberous roots (Fig. $4 \mathrm{~A}, \mathrm{C})$. However, the accumulation of GBSSI protein remained relatively steady regardless of tuberous root size (Fig. 4B,C). A similar observation was made for the small subunit of ADP-glucose pyrophosphorylase in potato leaves where the protein profile also failed to agree with the accumulation of transcript during photoperiod and sucrose induction (Nakata and Okita 1995). The lack of correlation between GBSSI transcript and protein accumulation might be the result of a post-transcriptional regulation. Since in vivo labeling data (Fig. 5) indicated that accumulation of newly synthesized GBSSI protein in starch granules did not increase with the size of the tuberous roots or the level of transcript, this difference in accumulation patterns might be due to (1) not all GBSSI transcripts were translatable, or (2) some GBSSI proteins synthesized were not partitioned into starch granules. Since this protein could not be detected in the soluble fraction (Fig. 2, lane 1), the second possibility could be ruled out. The first possibility was supported by a preliminary study of in vitro translation using total RNA extracted from tuberous roots of different sizes. The result 
did not show an increase in the amount of a $67-\mathrm{kDa}$ protein as the accumulation of GBSSI transcript increased (data not shown).

In leaves, starch synthesis and degradation have been shown to be influenced by rates of photosynthesis and photoperiod (Fondy et al. 1989, Li et al. 1992). However, other studies have indicated that starch metabolism is not only controlled by photosynthesis but also by a diurnal circadian component (Britz et al. 1987, Li et al. 1992). In $14 \mathrm{~h}$ light/10 $\mathrm{h}$ dark photoperiods, temporary starch of sugar beet leaves was accumulated during daytime and began to decrease at the end of the light period. However, the pattern of starch accumulation under continuous irradiance was similar to that of the $14 \mathrm{~h} \mathrm{light} / 10 \mathrm{~h}$ dark treatment. This circadian pattern could be controlled by enzymes either involved in starch synthesis or degradation. Further studies on carbon allocation in sugar beet leaves indicate that the decrease in starch accumulation was not caused by starch degradation (Li et al. 1992), suggesting that one or more enzymes in the starch synthetic pathway might be involved in regulating the rhythm. However, based on two enzymes studied, activities of ADPglucose pyrophosphorylase and phosphoglucose isomerase were not implicated in regulating the rhythm of starch metabolism in sugar beet ( $\mathrm{Li}$ et al. 1992). Our findings that the expression of the GBSSI gene shows a circadian rhythm (Fig. 6) may help to understand how carbon allocation in leaves is subjected to endogenous circadian regulation.

GBSSI may appear as several isoforms, and their expression is tissue-specific in some plant species (Denyer et al. 1997, Nakamura et al. 1998, Tomlinson et al. 1998). For example, pea contains GBSSI and GBSSIb with the former isoform expressed in embryos and the latter in leaves and pods (Denyer et al. 1997). GBSSIb is a GBSSI-like protein with different molecular mass. Although antigenic properties are similar between GBSSI and GBSSI-like isoforms, the homology of nucleotide sequences are not similar enough to produce cross-hybridization (Nakamura et al. 1998). On the other hand, the study on the potato amylose-free (amf) mutant indicates that amylose is synthesized by the same GBSSI in different tissues (Jacobsen et al. 1989). Our studies demonstrate that the GBSSI prepared from tuberous roots, leaves, and stems are identical in size and could all be recognized by the antiserum against the GBSSI of potato (Fig. 3). Furthermore, probing the genomic DNA with GBSSI cDNA produced only one genomic fragment in Southern hybridization (data not shown), and tuberous root GBSSI cDNA could cross-hybridize to the GBSSI mRNA of leaves and stems (Fig. 3). These results suggest that sweet potato contains only one GBSSI. However, regulation of GBSSI expression in the storage organ is different from that of the non-storage tissues. In the storage organ, GBSSI expression is controlled at a transcriptional level during development of tuberous roots, but circadian regulation is the dominant mechanism controlling expression of the same gene in non-storage tissues, e.g., leaves and stems.

Acknowledgements - We are grateful to Dr Richard G.F. Visser for his kind gift of potato GBSSI antibodies, and to Mei-Jung Wu for technical assistance. This research was supported by a grant NSC 85-2311-B-002-043 from the National Science Council of the Republic of China.

\section{References}

Abel GJW, Springer F, Willmitzer L, Kossmann J (1996) Cloning and functional analysis of a cDNA encoding a novel $139 \mathrm{kDa}$ starch synthase from potato (Solanum tuberosum L.). Plant J 10: 981-991

Baba T, Nishihara M, Mizuno $K$, Kawasaki T, Shimada H, Kobayashi E, Ohnishi S, Tanaka K, Arai Y (1993) Identification, cDNA cloning, and gene expression of soluble starch synthase in rice (Oryza sativa L.) immature seeds. Plant Physiol 103: $565-573$

Britz SJ, Hungerford WE, Lee DR (1987) Rhythms during extended dark periods determine rates of net photosynthesis and accumulation of starch and soluble sugar in subsequent light periods in leaves of Sorghum. Planta 171: 339-345

Clark JR, Robertson M, Ainsworth CC (1991) Nucleotide sequence of a wheat (Triticum aestivum L.) cDNA clone encoding the waxy protein. Plant Mol Biol 16: 1099-1101

Craig J, Lloyd JR, Tomlinson K, Barber L, Edwards A, Wang TL, Martin C, Hedley CL, Smith AM (1998) Mutations in the gene encoding starch synthase II profoundly alter amylopectin structure in pea embryos. Plant Cell 10: 413-426

DeFekete MAR, Leloir LF, Cardini CD (1960) Mechanism of starch biosynthesis. Nature 187: 918-919

Dellaporta SL, Wood J, Hicks JB (1983) A plant DNA mini preparation: Version II. Plant Mol Biol Rep 1: 19

Denyer K, Sidebottom C, Hylton CM, Smith AM (1993) Soluble isoforms of starch synthase and starch-branching enzyme also occur within starch granules in developing pea embryos. Plant $\mathbf{J}$ 4: $191-198$

Denyer K, Hylton CM, Jenner CF, Smith AM (1995) Identification of multiple isoforms of soluble and granule-bound starch synthase in developing wheat endosperm. Planta 196: 256-265

Denyer K, Barber LM, Edwards EA, Smith AM, Wang TL (1997) Two isoforms of the GBSSI class of granule-bound starch synthase are differentially expressed in the pea plant (Pisum sativum L.). Plant Cell Environ 20: 1566-1572

Devereux J, Haeberli P, Smithies O (1984) A comprehensive set of sequence analysis programs for the VAX. Nucleic Acids Res 12: $387-395$

Dry I, Smith A, Edwards A, Bhattacharyya M, Dunn P, Martin C (1992) Characterization of cDNAs encoding two isoforms of granule-bound starch synthase which show differential expression in developing storage organs of pea and potato. Plant J 2: $193-202$

Edwards A, Marshall J, Sidebottom C, Visser RGF, Smith AM, Martin C (1995) Biochemical and molecular characterization of a novel starch synthase from potato tubers. Plant J 8: 283-294

Edwards A, Marshall J, Denyer K, Sidebottom C, Visser RGF, Martin C, Smith AM (1996) Evidence that a $77-\mathrm{kDa}$ protein from the starch of pea embryos is an isoform of starch synthase which is both soluble and granule bound. Plant Physiol 112: 89-97

Edwards A, Fulton DC, Hylton CM, Jobling SA, Gidley M, Rössner U, Martin C, Smith AM (1999) A combined reduction in activity of starch synthases II and III of potato has novel effects on the starch of tubers. Plant J 17: 251-261

Fondy BR, Geiger DR, Servaites JC (1989) Photosynthesis, carbohydrate metabolism, and export in Beta vulgaris L. and Phaseolus vulgaris $\mathrm{L}$. during square and sinusoidal light regimes. Plant Physiol 89: 396-402

Furukawa K, Tagaya M, Inouye M, Preiss J, Fukui T (1990) Identification of lysine 15 at the active site in Escherichia coli glycogen synthase. J Biol Chem 266: 2086-2090

Goodbourn S (1996) Reverse transcriptase-polymerase chain reaction (RT-PCR). In: Docherty K (ed.) Gene Transcription RNA Analysis. John Wiley and Sons Ltd Press, Chichester, pp 68-71. ISBN 0-471-96147-7

Henikoff S (1984) Unidirectional digestion with exonuclease III creates targeted breakpoints for DNA sequencing. Gene 28: $351-359$

Hovenkamp-Hermelink JHM, Jacobsen E, Ponstein AS, Visser RGF, Vos-Scheperkeuter GH, Bijmolt EW, de Vries JN, Witholt B, Feenstra WJ (1987) Isolation of an amylose-free starch mutant of the potato (Solanum tuberosum L.). Theor Appl Genet 75: 217-221 
Hylton CM, Denyer K, Keeling PL, Chang MT, Smith AM (1996) The effect of waxy mutations on the granule-bound starch synthases of barley and maize endosperms. Planta 198 $230-237$

Jacobsen E, Hovenkamp-Hermelink JHM, Krijgsheld HT, Nijdam H, Pijnacker LP, Witholt B, Feenstra WJ (1989) Phenotypic and genotypic characterization of an amylose-free starch mutant of the potato. Euphytica 44: 43-48

Keegstra K, Olsen LJ, Theg SM (1989) Chloroplastic precursors and their transport across the envelope membranes. Annu Rev Plant Physiol Plant Mol Biol 40: 471-501

Klösgen RB, Gierl A, Schwarz-Sommer Z, Saedler H (1986) Molecular analysis of the waxy locus of Zea mays. Mol Gen Genet 203: $237-244$

Laemmli UK (1970) Cleavage of structural proteins during the assembly of the head of bacteriophage T4. Nature 227: 680-685

Larskey RA, Mills AD (1975) Quantitative film detection of ${ }^{3} \mathrm{H}$ and ${ }^{14} \mathrm{C}$ in polyacrylamide gels by fluorography. Eur $\mathrm{J}$ Biochem 56 : $335-341$

Lee L, Tsai CY (1985) Effect of sucrose accumulation on zein synthesis in maize starch-deficient mutants. Phytochemistry 24: 225-229

Li B, Geiger DR, Shieh WJ (1992) Evidence for circadian regulation of starch and sucrose synthesis in sugar beet leaves. Plant Physiol 99: 1393-1399

Marshall J, Sidebottom C, Debet M, Martin C, Smith AM, Edwards A (1996) Identification of the major starch synthase in the soluble fraction of potato tubers. Plant Cell 8: 1121-1135

Martin C, Smith AM (1995) Starch biosynthesis. Plant Cell 7 : 971-985

Müller-Röber B, Sonnewald U, Willmitzer L (1992) Inhibition of the ADP-glucose pyrophosphorylase in transgenic potatoes leads to sugar-storing tubers and influences tuber formation and expression of tuber storage protein genes. EMBO J 11: 12291238

Nakamura T, Vrinten P, Hayakawa K, Ikeda J (1998) Characterization of a granule-bound starch synthase isoform found in the pericarp of wheat. Plant Physiol 118: 451-459

Nakata PA, Okita TW (1995) Differential regulation of ADP-glucose pyrophosphorylase in the sink and source tissues of potato. Plant Physiol 108: 361-368

Nelson OE, Tsai CY (1964) Glucose transfer from adenosine diphosphate-glucose to starch in preparations of Waxy seeds. Science 145: 1194-1195

Okagaki RJ (1992) Nucleotide sequence of a long cDNA from the rice waxy gene. Plant Mol Biol 19: 513-516

Preiss J (1988) Biosynthesis of starch and its regulation. In: Preiss J (ed.) The Biochemistry of Plants, Vol. 14. Academic Press, New York, NY, pp 181-254. ISBN 0-12-675414-4

Rohde W, Becker D, Salamini F (1988) Structural analysis of the waxy locus from Hordeum vulgare. Nucleic Acids Res 16: 71857186
Salehuzzaman SNIM, Jacobsen E, Visser RGF (1993) Isolation and characterization of a cDNA encoding granule-bound starch synthase in cassava (Manihot esculenta Crantz) and its antisense expression in potato. Plant Mol Biol 23: 947-962

Sambrook J, Fritsch EF, Maniatis T (1989) Molecular Cloning: A Laboratory Manual, 2nd Ed. Cold Spring Harbor Laboratory Press, Cold Spring Harbor, NY. ISBN 0-87969-309-6

Sanger F, Nicklen S, Coulson AR (1977) DNA sequencing with chain-terminating inhibitors. Proc Natl Acad Sci USA 74: 5463-5467

Shennan KIJ (1996) Isolation of poly(A) ${ }^{+}$RNA. In: Docherty K (ed.) Gene transcription - RNA Analysis. John Wiley and Sons Ltd Press, Chichester, pp 18-19. ISBN 0-471-96147-7

Shure M, Wessler S, Fedoroff N (1983) Molecular identification and isolation of the Waxy locus in maize. Cell 35: 225-233

Tomlinson K, Craig L, Smith AM (1998) Major differences in isoform composition of starch synthase between leaves and embryos of pea (Pisum sativum L.). Planta 204: 86-92

Tomlinson KL, Lloyd JR, Smith AM (1997) Importance of isoforms of starch-branching enzyme in determining the structure of starch in pea leaves. Plant J 11: $31-43$

Tsai CL, Tsai CY (1990) Endosperm modified by cross-pollinating maize to induce changes in dry matter and nitrogen accumulation. Crop Sci 30: 804-808

Tsai CY (1973) The activities of maize $\alpha-1,4$ glucan glucosyltransferases in vitro. Bot Bull Acad Sin 14: 125-135

Tsai CY (1974) The function of the Waxy locus in starch synthesis in maize endosperm. Biochem Genet 11: 83-96

Tsai CY (1983) Genetics of storage protein in maize. In: Janick J (ed.) Plant Breeding Review, Vol. 1. AVI Publishing Co., Inc., Westport, CT, pp 103-138. ISBN 0-87055-397-6

Tsai CY, Larkins BA, Glover DV (1978) Interaction of the Opaque2 gene with starch-forming mutant genes on the synthesis of zein in maize endosperm. Biochem Genet 16: 883-896

van der Leij FR, Visser RGF, Ponstein AS, Jacobsen E, Feenstra WJ (1991) Sequence of the structural gene for granule-bound starch synthase of potato (Solanum tuberosum L.) and evidence for a single point deletion in the amf allele. Mol Gen Genet 228: $240-248$

Visser RGF, Somhorst I, Kuipers GJ, Ruys NJ, Feenstra WJ, Jacobsen E (1991a) Inhibition of the expression of the gene for granule-bound starch synthase in potato by antisense constructs. Mol Gen Genet 225: 289-296

Visser RGF, Stolte A, Jacobsen E (1991b) Expression of a chimaeric granule-bound starch synthase-GUS gene in transgenic potato plants. Plant Mol Biol 17: 691-699

Vos-Scheperkeuter GH, de Boer W, Visser RGF, Feenstra WJ, Witholt B (1986) Identification of granule-bound starch synthase in potato tubers. Plant Physiol 82: 411-416

Yeh KW, Juang RH, Su JC (1991) A rapid and efficient method for RNA isolation from plants with high carbohydrate content. Focus 13: 102-103

Edited by C. Larsson 